\title{
TRANSLITERATION, TRANSLATIONS, AND CITATIONS
}

I follow Library of Congress rules for transliteration from Russian with exceptions for names given in anglicized forms: Eisenstein, Kurbsky, Mosfilm (Eizenshtein, Kurbskii, and Mosfil'm in the notes and bibliography). I cite widely available English translations whenever possible; when I cite the original Russian publications, the translations are my own. The first citation of an archival source gives the abbreviated name of the archive and the fond, or collection, in which the document is found. Thereafter I give only the numbers of the opis (inventory), ed. khr. or delo (file), and list (page), separated by a forward slash, and a date if I have it, in brackets. Citations without a fond number are documents from Eisenstein's personal papers at RGALI, f. 1923. Titles cited in the notes without an author were written by Eisenstein.

Eisenstein often underlined and double-underlined text in his notes and manuscripts. These are underlined or underlined and bolded here. Eisenstein often used ellipses in his notes to convey emphasis. To avoid confusing these with punctuation meant to show words have been left out of a quotation, I give Eisenstein's ellipses as em-dashes. When I quote a text he originally wrote in English, I reproduce the English in italics, with its errors and idiosyncrasies intact. I also italicize text that appeared originally in French or German but marked with an additional note.

Some of the research that produced this book appeared in the following publications, reprinted here with permission: "Not a Film But a Nightmare: Revisiting Stalin's Response to Eisenstein's Ivan the Terrible, Part II," Kritika: Explorations in Russian and Eurasian History 19, no. 1 (2018): 115-42; "Another Dialectic: Eisenstein on Acting," in The Flying Carpet: Studies on Eisenstein in Honor of Naum Kleiman, ed. Joan Neuberger and Antonio Somaini (Paris: Éditions Mimésis, 2017): 255-78; "Sergei Eisenstein's Ivan the Terrible as History," Journal of Modern History 86, no. 2 (2014): 295-334; "The Music of Landscape: Eisenstein, Prokofiev, and the Uses of Music in Ivan the Terrible," in Sound, Speech, and Music in Russian Cinema, ed. Lilya Kaganovsky and Masha Salazkina (Bloomington: Indiana University Press, 2013): 212-29; "Eisenstein's 
Cosmopolitan Kremlin: Drag Queens, Circus Clowns, Slugs, and Foreigners in Ivan the Terrible," in Ours and Theirs: Outsiders, Insiders, and Otherness in Russian Cinema, ed. Stephen Norris and Zara Torlone (Bloomington: Indiana University Press, 2008): 81-95; and Ivan the Terrible: The Film Companion (London: I. B. Tauris, 2003).

Ivan the Terrible was released on DVD by Criterion Collection in 2003 in the boxed set Eisenstein: The Sound Years. This version also contains footage for Part III, some deleted scenes, and other material. In 2017, Mosfilm released a newly restored HD version, which is available with English subtitles online. Time codes to these videos are given in parentheses throughout the text for easy viewing while reading. As of this writing, it can be found here: http:// cinema.mosfilm.ru/films/film/Ivan-Groznyj/ivan-grozniy-1-ya-seriya/ and here:

Part I: https: / / www.youtube.com/watch?v=jJmsV10MTJE\&t=3306s

Part II: https: / / www.youtube.com/watch?v=i5g-Ss9BDR4\&t=1039s 